ppi $201502 Z U 4645$

Esta publicación científica en formato digital es continuidad de la revista impresa ISSN-Versión Impresa 0798-1406 / ISSN-Versión on line 2542-3185Depósito legal pp $197402 Z$ U34
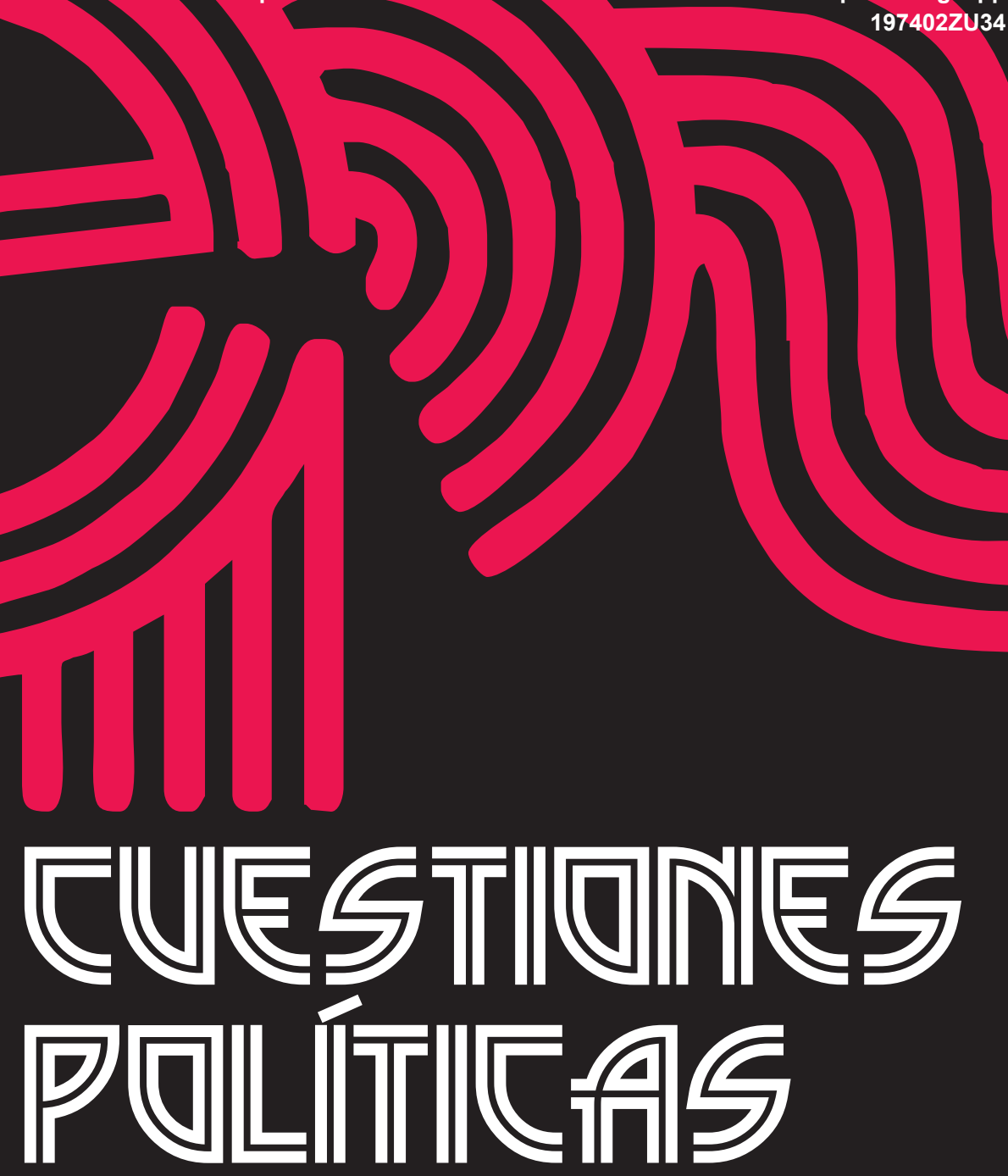

Instituto de Estudios Políticos y Derecho Público "Dr. Humberto J. La Roche" de la Facultad de Ciencias Jurídicas y Políticas de la Universidad del Zulia Maracaibo, Venezuela
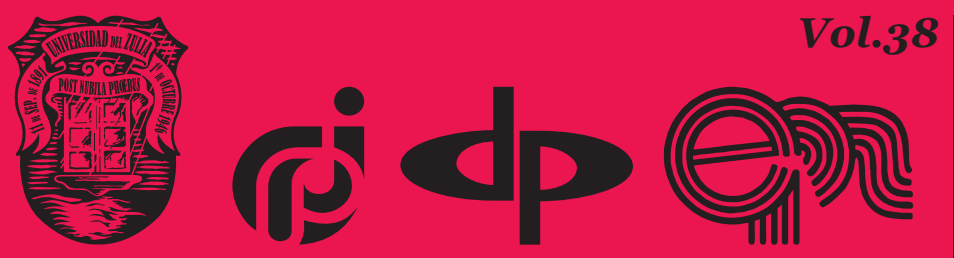

$N^{\circ}$ Especial 2da Parte 2020 


\title{
Conflicts associated with migratory processes: a political perspective
}

\section{DOI: https://doi.org/10.46398/cuestpol.382e.13}

\author{
Victoria Ravilevna Sagitova * \\ Andrey Valeryevich Ivanov **
}

\begin{abstract}
The objective of the research was to discuss the conflictive nature of the migratory processes that occur in the world today. The need to adapt and solve daily problems inevitably requires the State to implement international, state and regional standards for the implementation of the rights and opportunities of migrants both in the territory of the donor country and in the territory of the recipient country. On the other hand, we see an increase in the phobia of migrants and the characteristic racism of countries where labor migration flows are increasing. In methodological terms, use was made of hermeneutics close to political ethnography. It is concluded that, for a long time, the criticism of racism has developed as a criticism of colonialism, Nazism, including anti-Semitism, and in modern times as a political criticism of migration-phobia and nationalism, in which the Racist speech and practices have found and do find obvious and complete expression. Migrant phobia is a concept that latently generates motives of political, ideological, racial, national, religious hatred, xenophobia, or hostility towards an ethnic or social group within the framework of social
\end{abstract} practices.

Keywords: migratory processes; migratory phobia; educational migration; conflict of migratory processes; COVID-19.

Candidate of psychological Sciences, associate professor of the Department of Conflict Management of the Institute of Social and Philosophical Sciences and Mass Communications, Kazan (Volga state) Federal University, Tel: +79600648785. ORCID ID: https://orcid.org/oooo-00o1-7002-4719. Email: 12612682@mail.ru

** Candidate of Historical Sciences, associate professor of the Department of Conflict Management of the Institute of Social and Philosophical Sciences and Mass Communications, Kazan (Volga state) Federal University, Tel.: 89053115876. ORCID ID: https://orcid.org/oooo-0002-6491-6267. Email: Berserk2004@yandex.ru

Recibido el 15/06/2020 Aceptado el 22/10/2020 


\section{Conflictos asociados a los procesos migratorios: una mirada politológica}

\section{Resumen}

El objetivo de la investigación fue discutir el carácter conflictivo de los procesos migratorios que se dan en el mundo de hoy. La necesidad de adaptarse y resolver los problemas cotidianos requiere inevitablemente que el Estado implemente estándares internacionales, estatales y regionales para la implementación de los derechos y oportunidades de los migrantes tanto en el territorio del país donante como en el territorio del país receptor. Por otro lado, vemos un aumento de la fobia a los migrantes y el racismo característico de los países donde los flujos migratorios laborales están aumentando. En lo metodológico se hizo uso de la hermenéutica próxima a la etnografía política. Se concluye que, durante mucho tiempo, la crítica al racismo se ha desarrollado como una crítica al colonialismo, al nazismo, incluido el antisemitismo, y en los tiempos modernos como una crítica política a la migranto-fobia y el nacionalismo, en los que el discurso y las prácticas racistas han encontrado y encuentran una expresión obvia y completa. La fobia al migrante es un concepto que genera de forma latente motivos de odio político, ideológico, racial, nacional, religioso, xenofobia $\mathrm{u}$ hostilidad hacia un grupo étnico o social en el marco de las prácticas sociales.

Palabras clave: procesos migratorios; fobia migratoria; migración educativa; conflicto de procesos migratorios; COVID-19.

\section{Introduction}

The phenomenon of migration itself has a high level of conflict for most donor and recipient countries, since it requires resources for both adaptation and economic development processes, creating new jobs, and determining social guarantees for migrants and their families. In theoretical studies, migration processes are classified according to a specific type of migrant activity. Thus, it is customary to distinguish labor migration, educational migration, medical, tourist and other types.

Allthesetypes ofmigration processesare regulated at theglobal, interstate, regional, and national (state-level) levels. The mechanisms regulating these processes are dual in nature at the level of emerging contradictions between countries of emigration and countries of immigration (Global Commission on International Migration, 2006). 
Through cooperation agreements, programs for the admission of students, postgraduates, doctoral students, young professionals, labor migrants, and readmission of illegal migrants, the mechanism for interstate regulation of migration flows is working.

The mechanism of the national level of regulation of migration policy is the solution of issues that re-enter the territory of the state and previously entered illegally.

At all the above levels one can observe the consequences of migration processes expressed in:

- Geographic expansion of the boundaries of migration.

- Previously "sedentary population groups" - women and children in recent decades have been actively included in the migration flows of educational, tourist and labor migration.

- There are new forms of migration that are of a business nature (business migration), religious (religious pilgrimage) and tourist nature.

- Flows of criminal groups and the sale of less protected segments of the population into slavery are major problems in migration policy.

- Negative consequences of "replacement" migration is increasing.

- "Migrant diasporas" are increasing in the host countries and their influence on the host country's economy is increasing (Riazantsev and Bozhenko, 2010).

Cultural practices in the country of certain social groups of the transit population, namely migrants, can cause the local population to feel hatred, hostility, fear, envy, where these negative feelings are based on the inability to overcome cultural differences, and hence the avoidance of a full-fledged dialogue. Cultural and spiritual antagonism can be speculatively deduced from the fact that alien groups are to blame for the socio-economic misery of the autochthonous population.

A closer look at these types of migration will help to understand the extent of their conflict for both the host and donor countries.

\section{Methods}

The interpenetration of the phenomena of migrantophobia and ethnophobia lies on the surface: both migrants and representatives of other ethnic groups are "different", the relations of the local population with 
both are projected through the prism of relations "their" - "others" (Ivanov, 2017).

Factors of growth of ethno-and migrant-phobias are quite complex processes, and they cannot be explained unambiguously. Like all phobias, they are derived from fears of loss of "wealth" "resources" "influence" and "loss of one's own identity" (Ivanov, 2017).

Consider migration - educational. Educational migration includes not only education, professional development, but also various types of internships, additional education, and courses. The contingent of educational migration are students of secondary educational institutions, as well as categories receiving professional and postgraduate education postgraduates, doctoral students, trainees, professionals who improve their skills in various structures and companies.

According to the classification, educational migration is divided into relocation and scientific and educational migration (students and trainees in order to obtain new or specific competencies that are not available in their country) (Vyhovanets, 2007). Educational migration affects internal processes at the level of the country for the migrant (change of cities within the country) or external processes represented by international migration.

International educational migration includes:

1. educational immigration for secondary and first higher education, as well as various vacation programs.

2. immigration for the purpose of obtaining the second higher and subsequent levels of education, academic degrees, and scientific internships.

3. immigration for professional development (language courses, seminars, trainings, retraining programs, business education, etc.).

According to the forms of implementation, it is represented by full-time, part-time and the most popular form of distance learning in recent years.

If the full-time training of migrants gives the host country an effect in at least four areas of society - social, political, demographic, economic and political, then the other types of temporary effect occurs or it is not yet possible to assess it.

In the case of migration within the country, nothing actually changes for the student, except for the need to learn new behaviors inherent in the population of a particular city, while for foreign students there are drastic changes, to adapt to which sometimes you need outside support and assistance. 
Victoria Ravilevna Sagitova y Andrey Valeryevich Ivanov
184 Conflicts associated with migratory processes: a political perspective

Distance education is more specific, since the time spent in the country of study is reduced, temporary, which greatly facilitates adaptation and makes it possible to master and then translate the norms and values of the city and country of study upon returning home.

The distance form of providing educational services, which has been actively developing in recent decades, is becoming more and more widespread and is being integrated into the system of international relations as an integral part of building international relations.

One of the positive consequences of educational migration is, provided that the student remains in the country or city of education to work, the entry into the labor market of a certified specialist who meets the requirements of this country or city for a set of formed competencies. At the same time, this can also be considered as a negative component due to poor knowledge of the recipient country's language, poor adaptation and, consequently, a set of insufficient competencies for integration into the economy. But, by and large, the problem will be ambitions and claims for employment with a good salary.

Hence, the second type of migration - labor-acquires a new character of relations, since it reflects the processes of adaptation to the sphere of work among those who entered the territory of the recipient country illegally, those who enter with high qualifications and those who, having learned and adapted in the country, find employment. In all these cases, the nature of the employment relationship will differ.

The main goal of labor migration is to find better living conditions in developed countries. On the part of the host States-solving demographic problems and attracting additional workers. This type of migration has both positive and negative consequences. The positive ones include cheaper production of goods and services, therefore, increased competitiveness, thereby increasing demand for domestic goods, with official employment - the payment of taxes to the Treasury of the recipient country, but at the same time the lack of participation in social programs.

The negative consequences are the growth of unemployment among the local skilled population due to the cheapening of their labor, the "leakage" of Finance from the country in the form of money transfers to donor countries. But the key is the social component of the relations that migrants enter with the local population - an increase in the share of conflicts with the local population at the domestic level, rivalry between ethnic groups against the background of religious and cultural traditions.

According to the form of labor migration, it is also divided into "fulltime" and "virtual". 
The digital revolution has made it possible to expand the scope of labor migration to virtual space and remote forms of work among highly qualified workers. Highly qualified specialists do not need to move geographically, they basically create a "knowledge economy" that obeys the "code rule" (Aneesh, 2008). a business space is Formed based on virtual migration. It is a test for the economies of recipient countries on the quality of migrant workers. By and large, this is a test for "brain drain" (Aneesh, 2006).

Most often, virtual labor migration is associated with professionals in the field of information technology, but no one excludes cases of remote work abroad. The need for highly qualified specialists will grow due to increasing globalization and the places of low-skilled workers will be occupied by robotic systems that can be controlled remotely (Heaven, 2017).

The next major direction of development of migration processes is tourist migration. It is a process of cultural globalization. The positive consequences of this type of migration processes are the establishment and expansion of international contacts, the reduction of spatial distance, and the study of the "lifestyle" of the visiting population. All this contributes to the strengthening of cooperation between countries, starting from the everyday levels of communication. In the future, tourist migration can become the basis for labor and educational migration.

So, aggressive migration from Asia and Africa, the global economic crisis, and the failure of the multiculturalism process in Western Europe create new opportunities for activating migrant phobia, as well as rightwing radical actions and power actions.

\section{Results and Discussion}

The globalization of immigration processes inevitably leads to the fact that there is a question not only of adapting migration flows to the economy, politics, society and other areas of social structure, but also of internal and external conflicts in the migration processes themselves.

- Today, migration as a global phenomenon can have negative consequences (bearing a conflict-causing nature), such as:

- Expanding the geographical boundaries of migration.

- Involvement of previously " sedentary segments of the population».

- Negative impact of "replacement" migration, which inevitably leads to conflicts of interest.

- "Diasporization" of economic relations. 
If we return to the international, state and regional levels of consideration of the conflict nature of migration processes, it becomes clear that the negative consequences of migration are expressed in conflicts of interest at the economic and political levels, inter-ethnic conflicts, conflicts of adaptation, and conflicts of a domestic nature.

The insistence on exaggerating the criminal tendencies of ethnic minority migrants can easily be explained by the peculiarities of the human psyche. This psychological mechanism is called "illusory correlation".

It has been demonstrated that people, first of all, create stereotypes under the impression of rare phenomena and attach much more weight to them than they deserve.

Second, the group is assigned the most positive moral qualities that distinguish it from other groups.

Third, due to these features, negative stereotypes about the qualities of "outsiders" are transferred from their individual representatives to the entire groups to which they belong (Hamilton and Gifford, 1976).

Thus, this mechanism functions depending on the initial, positive or negative, emotional mood that affects the distortion of the real picture in one direction or another (Stroessner et al., 1992).

Within the framework of virtual labor migration, conflicts are mostly legal in nature, since they are mainly related to the following issues:

- registration of employment contracts for "virtual migrants" to "remote" jobs.

- protection of their rights in case of disputes between the employee and the employer.

- the amount of remuneration.

- being treated as "outsiders" in matters of privileges from an organization or country.

- lack of social guarantees in the field of social policy of the recipient country if you want to physically immigrate.

- the need to periodically earn your "trust bonus" in a "remote" workplace and constantly maintain it in a larger volume than in fulltime work.

Educational migration is less conflict-prone due to the fact that the age group of students in schools and universities in other countries is quite plastic in its attitudes and values, and the receipt of education by postgraduates and doctoral students a priori sets quite wide boundaries of the worldview for the acceptance of the culture and values of the recipient country's population. 


\section{Conclusions}

The migration policy pursued by the majority of countries is the result of internal political processes that take place at the level of both a single state and the totality of all States in the world.

Anti-immigrant positions are based on the following arguments:

1. uncontrolled influx of migrants leads to a complication of the social situation, can destabilize the labor and housing market, and contributes to an increase in the burden on social infrastructure.

2. migration worsens the sanitary and epidemiological situation.

3. migration contributes to the criminalization of the situation and the growth of crime.

4. non-ethnic migrants can take dominant positions in socio-economic life; the role of factors of inter-ethnic tension and conflict, such as ethnic infavoritism and clientism, increases sharply.

The ongoing changes introduced to the way of States by migration processes usually have ambivalent consequences.

Acute socio-political problems within countries sometimes cause protest and a sense of injustice and resentment among citizens who relate to their group. This dissatisfaction on the part of society is projected onto the immigrants. Recorded data are primarily directed at ethnic migrants, regardless of their citizenship, whether they are temporary labor migrants (migrant workers), whether they are resettled for permanent residence within Russia (migrants) or from abroad (immigrants).

\section{Acknowledgements}

The work is performed according to the Russian Government Program of Competitive Growth of Kazan Federal University.

\section{Bibliographic References}

ANEESH, Aneesh. 2006. Virtual migration: The programming of globalization. Duke univ. press. Durham, United States. 
Victoria Ravilevna Sagitova y Andrey Valeryevich Ivanov

ANEESH, Aneesh. 2008. Virtual migration: digital globalization. Social and human Sciences. Domestic and foreign literature. Ser. 8, Naukovedenie: Abstract Journal. Kazan, Russia.

GLOBAL COMMISSION ON INTERNATIONAL MIGRATION. 2006. Compendium of Recommendations on International Migration and Development: The United Nations Development Agenda and the Global Commission on International Migration Compared (Vol. 255). United Nations Publications.

HAMILTON, David; GIFFORD, Robert. 1976. "Illusory correlation in interpersonal perception: Cognitive basis of stereotypic judgements" In: Journal of experimental social psychology. Vol. 12, No. 4, pp. 392-407.

HEAVEN, Douglas., 2017. The next best thing to teleportation. BBC Future Now. Available online. In: https://www.bbc.com/future/article/20170113the-next-best-thing-to-teleportation. Consultation date: 27.05.2020.

IVANOV, Alexander. 2017. "Portrait of a neo-racist in the coordinate system «friend-foe» in social networks" In: Kazan pedagogical magazine. Vol. 5, pp. 153-157.

IVANOV, Alexander. 2017. Destructive strategies in social networks and the philosophy of anti-immigration. Activities of law enforcement agencies to counter extremism and terrorism: materials of the all-Russian round table (edited by S. N. Mironov). KUI MVD of Russia. Kazan, Russia.

RIAZANTSEV, Sergey; BOZHENKO, Vitaly. 2010. "Migration in the conditions of globalization” In: Population. Vol. 4, pp. 70-82.

STROESSNER, Steven; HAMILTON, David; MACKIE, Diane. 1992. "Affect and stereotyping: The effect of induced mood on distinctiveness-based illusory correlations" In: Journal of Personality and Social Psychology. Vol. 62, No. 4, p. 564.

VYHOVANETS, Olivia. 2007. Management of migration processes. Migration and development. Moscow, Russia. 
Vol.38 NEspecial

Esta revista fue editada en formato digital y publicada en diciembre de 2020, por el Fondo Editorial Serbiluz, Universidad del Zulia. Maracaibo-Venezuela 